Rev.MVZ Córdoba 17(2):3059-3064, 2012.

COMUNICACIÓN BREVE

\title{
Occurrence and identification of yeasts in dogs external ear canal with and without otitis
}

\section{Ocurrencia y detección de levaduras en el conducto auditivo de los perros con y sin otitis}

\author{
Elidiana de Bona, ${ }^{1}$ Esp, Sergio Ubiratan Paz Telesca, ${ }^{2} \mathrm{MV}$, \\ Alexandre Meneghello Fuentefria, ${ }^{3 *}$ Ph.D.
}

\begin{abstract}
${ }^{1}$ Universidade Comunitária Regional de Chapecó, UNOCHAPECÓ, Efapi, Chapecó, Brasil. ${ }^{2}$ Médico Veterinário Autônomo. 3Universidade Federal do Rio Grande do Sul, UFRGS. Departamento de Análises. Porto Alegre, Brasil. Correspondence: alexmf77@gmail.com
\end{abstract}

Recibido: Diciembre de 2009; Aceptado: Diciembre de 2011.

\begin{abstract}
Objective. To analyze the presence of yeast in the external ear canal of 116 dogs with and without a diagnosis of otitis from veterinary clinic in the Chapecó city, Santa Catarina, Brazil, and to examine the secretion of the proteinase in isolates. Materials and methods. Were collected cerumen of conduct hearing of dogs of 16 different races $71 \%$ with pendular ear type, $5 \%$ of semi-pendular and $24 \%$ of the erect type. All dogs were previously evaluated by otoscopy and grouped in dogs with and without otitis. Results. Yeasts were isolated in 44 samples (approximately $36 \%$ ), where Malassezia pachydermatis was identified in $95 \%$ of samples where were observed growth of yeasts. On 20 samples the proteinase enzyme showed strong activity in $31 \%$ isolates, were $21 \%$ of the dogs with otitis tested showed high proteolytic activity. Conclusions. We observed a variation of strains of $M$. pachydermatis-producing enzymes. The variation in production of these enzymes is probably more associated with different response to the action of the immune system of the animal in the tissue injury.
\end{abstract}

Key words: Dog, Malassezia pachydermatis, otitis, proteinases (Fuente: CAB).

\section{RESUMEN}

Objetivo. Se investigó la presencia de levaduras en el canal externo del oído de 116 perros de la clínica veterinaria en la ciudad de Chapecó, Santa Catarina,Brasil, en perros sanos y perros con otitis y se examinó la secreción de la proteinasa en las muestra aisladas. Materiales y métodos. Se recogieron cerumen del oído de perros de 16 razas diferentes, dónde $71 \%$ fue de oído de tipo pendular, $5 \%$ de semi-pendular y $24 \%$ del tipo erecto. Todos los perros fueron evaluados previamente por otoscopia y agrupados en perros con y sin otitis externa. Resultados. Las levaduras se aislaron en 44 muestras (aproximadamente 36\%), donde Malassezia pachydermatis se identificó en el $95 \%$ de las muestras donde se observó el crecimiento de las levaduras. El 20 muestras la secreción de proteinasa mostró fuerte actividad en el $31 \%$ de los aislados y en $21 \%$ de los perros con otitis mostró alta actividad proteolítica. Conclusiones. Hemos observado una variación de cepas de M. pachydermatis productoras de enzimas. La variación en la producción de estas enzimas es probablemente más asociados con la respuesta diferente a la acción del sistema inmunológico del animal en la lesión tisular.

Palabras clave: Malassezia pachydermatis, otitis, perro, proteinasa (Source: $C A B$ ). 


\section{INTRODUCTION}

Otitis is an inflammation of the dog ear canal, it can be classified as site on external, media and internal and also classified as an agent in seborrheic, parasitic, allergic, bacterial or fungal. It represents 8 to $15 \%$ cases seen in veterinary clinics in Brazil $(1,2)$. Otitis chronic is common on dogs with pendulous ears or animals with others skin diseases as atopic seborrheic dermatitis and that were treated with antibacterial drugs (3). The importance of dog otitis has magnitude when considered its effects as excessive ear secretion, foul smell, itches, agitation and pain. This situation leaves the dogs owners to look for the quick resolution taking the empirical treatment.

The microbiota of external ear canine consists of cocci Gram-positives, sticks Gram-negatives and Malassezia pachydermatis (2). The identification of yeasts is usually carried out through of morphological and biochemical findings, that include appearance and the colony morphology, size, presence of capsule, presence of hyphae or pseudo-hyphae, production of germ tube, production chlamydospore and assimilation biochemical tests (4).

M. pachydermatis is a microorganism of microbiota ear and skin of domestic carnivores (5). This organism has been isolated from healthy dogs with external otitis or from dogs with dermatitis. Factors that alter the local microclimate, providing moisture, temperature and substrate, stimulate the growth of the yeast cells, causing the change to commensal from parasitism (6).

Furthermore, the M. pachydermatis it comes as an isolated cells or grouped cell, with oval formate or with single polar budding of wide base, acquiring the form of "bottle". The pseudohyphae is usually absent. The cultivation is done in Sabouraud agar plus chloramphenicol and cycloheximide at $37^{\circ} \mathrm{C}$ from 2 to 6 days, and the absence of lipids do not prevent their growth (6). Single member of the genus that grow without supplementation of lipids (7). The yeast colonies are opaque, creamy yellow in color through orange to brown. Surface round or dome-shaped, dry texture, friable and granular, and sometimes fat, measured after five days of incubation $5 \mathrm{~mm}$ in diameter (6).

To facilitate the tissue invasion, some microorganisms produce hydrolytic enzymes that destroy or lose the balance of the formation of the membrane, causing disruption. Based on the observation of the genus Candida species has been shown that samples of $M$. pachydermatis isolated from the conduct of hearing dogs with otitis are also able to produce these enzymes (8). The proteolytic enzymes are part of the metabolic system of a large number of living organisms, can that be isolated from animal, vegetable or microorganisms and it is are classified as proteases and peptidase. The most proteases are quantitative detected in vitro using as substrate solid medium containing casein, gelatin, bovine albumin serum and others proteins (9).

The objective of this paper was analyze the presence of yeast in the ear canal of dogs with and without a diagnosis of otitis from veterinary clinic in the Chapecó city, Santa Catarina, and to examine the secretion of the proteinase in isolates.

\section{MATERIALS AND METHODS}

Samples and animals. Were collected 116 samples to conduct headset from healthy dogs and from dogs with otitis in the veterinary clinic. Samples were collected by the professional veterinarian with sterile swab and transported in the tube containing BHI microbiology laboratory where, sequentially, were plated on Sabouraud agar plates were incubated at a temperature of 30 to $37^{\circ} \mathrm{C}$ for 48 to 72 hours where, as the growth characteristics of colonies of yeast, it was confirmed by direct examination of the colony with methylene blue showing the characteristic of yeast cells. Then it was proceeded to slide in microculture technique for observation of micromorphological characteristics to determine the species of yeast involved.

Laboratory analysis. The determination proteinasis was checked by hydrolysis of casein according with Fuentefria; Valente (2005) (10). Tested in Petri plates with Yeast Nitrogen Base (YNB) $0.67 \%$ medium add $0.5 \%$ glucose, $0.5 \%$ casein and $2 \%$ agar adjusted for $\mathrm{pH} 7.0$ with $\mathrm{KOH} 5 \mathrm{~N}$.

The suspension was standardize for 1 the MacFarland scale, was inoculate on duplicity 10 $\mu \mathrm{L}$ in equal distance on the medium. Seven days after, at $25^{\circ} \mathrm{C}$, was added $\mathrm{HCl} 1 \mathrm{~N}$ on the medium showing the production through transparent halo around in the colony. The production was classified on non productor (no halo), poor (halo of $1 \mathrm{~mm}$ ), medium (halo of $1-2 \mathrm{~mm}$ ) and strong (halo of $2-4 \mathrm{~mm}$ ). 


\section{RESULTS}

Of the 116 samples of cerumen collected with sterile swab of the external ear canal,34 (29.3\%) were dogs with otitis and 82 (70.7\%) were healthy dogs. The sample was constituted by $71 \%$ dogs with ear-type pendulous, $5 \%$ semi-commuting and $24 \%$ of the erect ears according to table1.
In the fungi cultivation, yeast were isolated in 44 samples (approximately 36\%), Malassezia pachydermatis was identified in $95 \%$ of samples where were observed growth of yeasts. On 20 samples, approximately $17 \%$ showed no growth of any microorganism and bacteria were isolated in 51 samples, approximately $45 \%$, as showed in figure 1.

Table 1. Classification of breeds of animals studied that the shape of the ear and number of samples by races.

\begin{tabular}{|c|c|c|c|c|c|c|c|c|}
\hline \multicolumn{9}{|c|}{ Classification by the shape of the ear of dogs } \\
\hline \multicolumn{3}{|c|}{ Pendulous } & \multicolumn{3}{|c|}{ Semi-pendulous } & \multicolumn{3}{|c|}{ Erect } \\
\hline Races & Frequency & $\begin{array}{c}* * \text { Frequency } \\
(\%)\end{array}$ & Races & Frequency & $\begin{array}{c}* * \text { Frequency } \\
(\%)\end{array}$ & Races & Frequency & $\begin{array}{c}* * \text { Frequency } \\
(\%)\end{array}$ \\
\hline Poodle & 23 & 20 & Bulldog & 5 & 4 & Yorkshire & 17 & 15 \\
\hline Lhasa-apso & 18 & 15.5 & $\begin{array}{l}\text { Chow- } \\
\text { chow }\end{array}$ & 1 & 1 & $* \mathrm{SRD}$ & 6 & 5 \\
\hline Shih-tzu & 12 & 10 & - & - & - & Pinscher & 4 & 3 \\
\hline Maltes & 12 & 10 & - & - & - & $\begin{array}{l}\text { Pastor } \\
\text { alemão }\end{array}$ & 1 & 1 \\
\hline $\begin{array}{c}\text { Dachsund/ } \\
\text { Teckel }\end{array}$ & 4 & 3.5 & - & - & - & - & - & - \\
\hline $\begin{array}{l}\text { Golden } \\
\text { retriever }\end{array}$ & 4 & 3.5 & - & - & - & - & - & - \\
\hline Labrador & 4 & 3.5 & - & - & - & - & - & - \\
\hline $\begin{array}{l}\text { Cocker } \\
\text { spaniel }\end{array}$ & 2 & 2 & - & - & - & - & - & - \\
\hline Pug & 2 & 2 & - & - & - & - & - & - \\
\hline Bichon-frise & 1 & 1 & - & - & - & - & - & - \\
\hline Total & 82 & 71 & Total & 6 & 5 & Total & 28 & 24 \\
\hline
\end{tabular}

$\mathrm{SRD} *$ (mixed breed) ** approximately

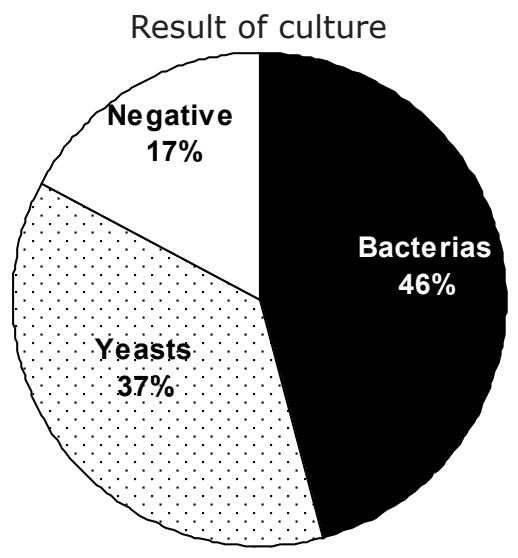

Figure 1. Result of culture of samples from ear of dogs with otitis and healthy dogs.
The samples of dogs with otitis, yeast were isolated on $41 \%$, being isolated only one sample of Candida glabrata and one sample of Rhodotorula sp. in healthy dogs, according table 2.

Within forty-four samples that showed growth of yeast, 39 were tested for production of proteinase. Of these, 14 were from dogs with otitis and 25 from healthy dogs. In the 25 $(64 \%)$ isolates were not producing the enzyme and that the sample of dogs with otitis, 9 (64\%) showed negative results. Showed strong activity in $12(31 \%)$ isolates, were $3(21 \%)$ of the 14 dogs with otitis tested showed high proteolytic activity.

The strong activity were showed on 12 (31\%) of all samples and 3 (21\%) of samples from dogs with otitis, according to table 3 and figure 2 . 
Table 2. Isolation of yeasts in analyzed samples.

\begin{tabular}{cccccc}
\hline & \multicolumn{3}{c}{ Isolation of yeasts } & & Healthy dogs \\
\hline Positive $(\%)$ & Negative $(\%)$ & Total $(\%)$ & Positive $(\%)$ & Negative $(\%)$ & Total $(\%)$ \\
$14(41 \%)$ & $20(59 \%)$ & $34(100 \%)$ & $30(37 \%)$ & $52(63 \%)$ & $82(100 \%)$ \\
\hline
\end{tabular}

Table 3. Production of proteinase enzyme of samples that showed the growth of yeasts.

\begin{tabular}{ccc}
\hline & Production of Proteinase & \\
Sample & Results & N of samples $*(\mathbf{\%})$ \\
\hline \multirow{2}{*}{ With otitis } & Negative & $16 *(64 \%)$ \\
& Media & $1 *(4 \%)$ \\
& Strong & $8 *(32 \%)$ \\
Otitis without & Negative & $9 *(64 \%)$ \\
& Media & $1 *(7 \%)$ \\
& Strong & $4 *(29 \%)$ \\
\hline
\end{tabular}

* Approximately

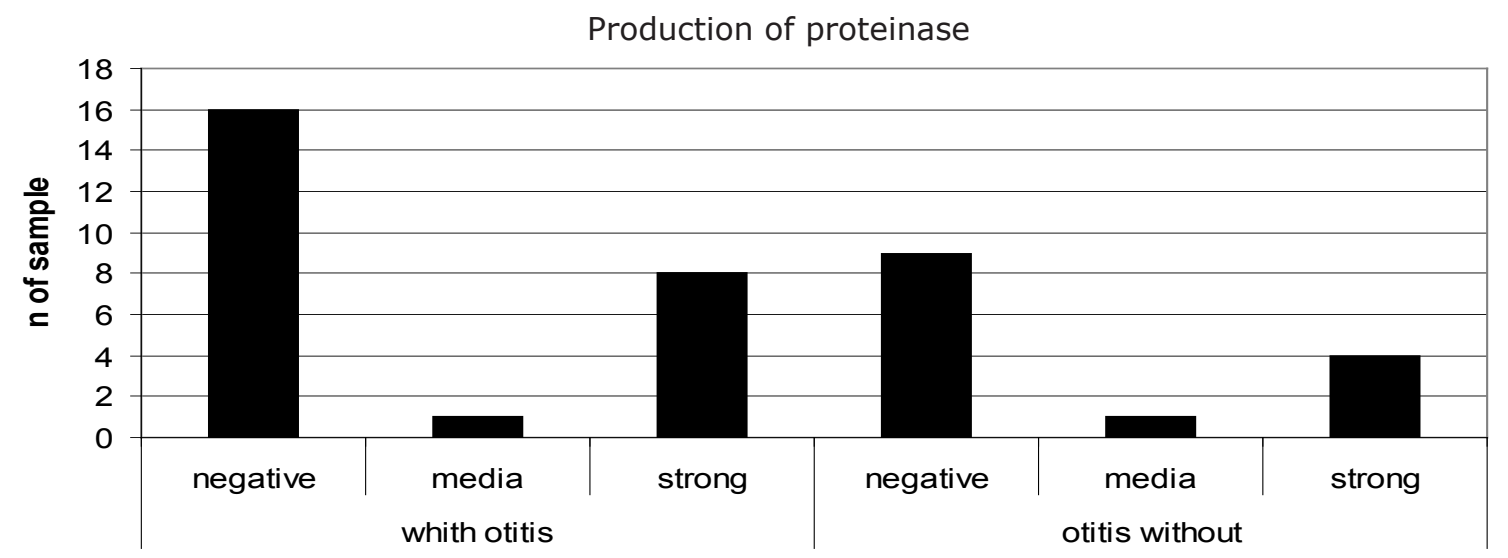

Figure 2. Relationship of the isolates of yeast in dogs with otitis and healthy dogs and production of virulence enzyme.

\section{DISCUSSION}

In the corresponding period, it was obtained samples of dogs with otitis bigger than Leite (1) and Bonates (2). According to these researchers, cases of otitis correspond to approximately $15 \%$ of demand in veterinary clinics. This different percentage can be explained proper by the differents types of the sample, for example, ear type, breed, age, sex, and others factors.

In this study the presences of yeast in dogs with pendulous ears while the result of positive mycological cultures in other studies. The mycological results on dogs with pendulous ears varied by $65 \%$ of the study by Bernardo et al (3) and $71 \%$ of the results found by Nobre et al (6).
The reason for the most incidence of yeasts in the conduct of hearing dogs with pendulous ears is probably due to the fact that these dogs are prone due to poor ventilation and increased accumulation of moisture in the ear canal (11), but do not have relationship with temperature, because the shape of the ear does not change the temperature. The temperature it keeps around $38.20^{\circ} \mathrm{C}$ to $38.40^{\circ} \mathrm{C}$, with no difference between races or between having or not ear commuting (12).

In this study, the isolation of yeasts, Malassezia pachydermatis mainly, were into the results on other studies when the isolates varied from 12 to $88 \%$ the isolates of yeasts. 
Girão et al (13), in 2006 studied the role of Malassezia pachydermatis as a pathogenic agent in canine otitis and found cytologically and culturally, this pathogenic yeast, in $57.53 \%$ of isolates. Tuleski et al (14) found in their study $54 \%$ of dogs studied, being $99 \%$ of Malassezia pachydermatis and Nobre et al (15) to study the frequency of infectious agents in otitis and dermatitis in dogs, found $25 \%$ of positive results for samples of Malassezia pachydermatis in healthy dogs and $80 \%$ in samples from dogs with otitis.

Santos (5) observed that in 110 cases of otitis analyzed, only $12 \%$ showed growth of Malassezia pachydermatis, this finding contrasts with the results found by Oliveira et al (16) that resulted in $65 \%$ growth of Malassezia pachydermatis and $14 \%$ of other yeasts of the genus Candida. Still et al (17) obtained high rates of isolation, $88 \%$ of cultures were carried out growth of Malassezia pachydermatis, while Borges et al (18) found above findings, the isolation of Malassezia spp. in $92 \%$ and Candida spp. in $16 \%$ of the sample.

Harvey et al (12) claim that Candida spp. occurrence is rare in domestic animals, which was confirmed in the results of this study by the isolation of only one sample of Candida glabrata.

Few studies report the appearance of Rhodotorula in canine infections, more specifically in canine otitis, however in Brazil, Duarte et al (19), related that in 45 cultures of pathogenic yeasts isolated from this external otitis in Sabouraud dextrose medium, revealed the growth of five (11.1\%) Rhodotorula mucilaginosa. In this case, as well as our study, this yeast is found in soil, may have been momentarily carried by the hair of the dog which was isolated, as it pertains to race, Lhasa-apso, with pendulous ears and with abundant hair.

Also few studies deal with the change of the saprophyte to parasite of Malassezia pachydermatis, Nobre et al (6) states that factors that alter the microenvironment, providing moisture in the case of pendulous ears, substrate and temperature stimulate the increase the number of cells with yeast entails a change to parasitism.

Coutinho (8) examined the secretion of virulence of four enzymes (proteinase, phospholipase, hyaluronidase and chondroitin-sulphatase) in 30 strains of Malassezia pachydermatis from healthy dogs and dogs with otitis without showing high secretion of proteinase in the two sample types (otitis / healthy). These findings differ from results on this study that dogs with otitis and in healthy dogs most of the isolates showed no secretion of the enzyme.

When comparing the results among the samples tested (otitis/healthy) it was observed that the samples that were secreted proteinase in the next two, showing no results so that they can consider the secretion of the enzyme as an isolated factor for the production of virulence.

In a recent study, Silveira (9) found the production of this enzyme in cultures and in culture monocellular and not monocellular for physiological characterization of Malassezia spp. species and concluded that the results can vary depending on the physiological characteristics of the biotypes, as a pure original sample may be different biotypes that can express different results. This characteristic was observed in this study, when different strains of $M$. pachydermatis, showed different variation in the production of enzymes.

In conclusion, we observed a variation of strains of $M$. pachydermatis-producing enzymes isolated from external ear canal of healthy dogs and with otitis. Our study demonstrated that the variation in production of these enzymes is probably associated with different response to the action of the immune system of the animal in the tissue injury. Subsequent studies involving parasite-host interaction should beconducted to better understand the virulence factors expressed by M. pachydermatis. 


\section{REFERENCES}

1. Leite C. As otites de cães e gatos: Epidemiologia. Rio de Janeiro: Guanabara Koogan; 2000.

2. Bonates A. Otite: conhecimento detalhado permite diagnósticos precisos e sucesso no tratamento. Vet News 2003; 62:6-8.

3. Bernardo FM, Martins HM, Martins ML. A survey of mycotic otitis externa of dogs in Lisbon. Rev Iberoam Micol 1998; 15:163-165.

4. Sidrim JJC, Moreira, JLB. Fundamentos clínicos e laboratoriais da micologia médica. Rio de Janeiro: Guanabara Koogan, 1999.

5. Santos RR. Sensibilidade in vitro da microbiota da orelha de cães com otite externa a cinco antimicrobianos. Acta Sci Vet 2007; 35:433-435.

6. Nobre MO, Meireles MCA, Gaspar LF, Pereira D, Schramm R, Schuch LF. Malassezia pachydermatis e outros agentes infecciosos nas otites externas e dermatites em cães. Ciência Rural 1998; 28:447-452.

7. Quinn PJ. Microbiologia veterinária e doenças infecciosas. Porto Alegre: Artmed; 2005.

8. Coutinho SDA. Malassezia pachydermatis: enzymes production in isolates from external ear canal of dogs with and without otitis. Arq Bras Med Vet Zootec 2005; 57:149-153.

9. Silveira ACB. Caracterização fisiológica de culturas não monocelulares e monocelulares de espécies de Malassezia. RBAC 2006; 38:213-216.

10. Fuentefria $A M$, Valente P. Screening of enzyme-producing yeast and yeast-like fungi from the phylloplane of Hibiscus rosa-sinensis in Brazil. Tecno-Lógica 2005; 9:9-25.

11. Nardoni S, Corazza M, Mancianti F. Diagnostic and clinical features of animal malasseziosis. Parassitologia 2008; 50: 81-83.
12. Harvey RG, Hararis J, Delauche AJ. Doenças do ouvido em cães e gatos. Rio de Janeiro: Revinter, 2004.

13. Girão $M D$, Prado $M R$, Brilhante RS, Cordeiro RA, Monteiro AJ, Sidrim JJ, Rocha MF. Malassezia pachydermatis isolated from normal and diseased external ear canals in dogs: a comparative analysis. Vet J 2006; 172:544-548.

14. Tuleski GLR, Warth JFG, Montiani-Ferreira $F$. Prevalência infecciosa em otites de cães e padrão de sensibilidade in vitro aos antibacterianos. A hora veterinária 2008; 162:27-33.

15. Nobre MO, Castro AP, Nascente PS. Occurrence of Malassezia pachydermatis and other infectious agents as cause of external otitis in dogs from Rio Grande do Sul state, Brazil (1996/1997). Braz J Microbiol 2001; 32:245-249.

16. Oliveira LC. Perfil de isolamento microbiano em cães com otite média e externa associadas. Arq Bras Med Vet Zootec 2006; 58:1009-1017.

17. Leite CAL, Abreu VLB, Costa GM. Freqüência de Malassezia pachydermatis em otite externa de cães. Arq Bras Med Vet Zootec 2003; 55:102-104.

18. Borges KDA. Eficácia clínica da gentamicina, cetoconazol e betametasona para o tratamento da otite externa de cães e gatos. A hora veterinária 2006; 26:37-40.

19. Duarte ER, Resende JC, Rosa CA, Hamdan JS. Prevalence of yeasts and mycelial fungi in bovine parasitic otitis in the State of Minas Gerais, Brazil. J Vet Med B Infect Dis Vet Public Health 2001; 48:631-635. 